\title{
Analisis Kandungan Klorofil Daun Jilat (Villebrune rubescens, Bl.) Pada Tingkat Perkembangan Berbeda
}

\section{Analysis Of Chlorophyll Content Of Daun Jilat (Villebrune rubescens Bl.) At Different Development Levels}

\section{Leonardo Elisa Aisoi}

Program Studi Pendidikan Biologi, Jurusan Pendidikan MIPA, FKIP, Universitas Cenderawasih Koresponden: leon_aisoi@yahoo.com

\begin{abstract}
Abstrak
Penelitian tumbuhan daun Jilat (Villebrune rubescens B1.) telah dilakukan dengan tujuan untuk menganalisa kandungan pigmen klorofil daun Jilat ( $V$. rubescens) pada tingkat perkembangan berbeda. Komposisi pigmen utama dianalisa menggunakan metode KLT berdasarkan warna totol dan nilai retardasi faktor. Hasil penelitian menunjukkan bahwa tumbuhan daun Jilat (V. rubescens B1.), mempunyai komposisi pigmen utama yang sama yaitu karoten, feofitin a, klorofil a, klorofil b dan ksantofil. Terdapat perbedaan warna pada daun muda dan dewasa, namun dari hasil pengukuran kandungan klorofil menunjukan absorbansi yang sama, yaitu pada panjang gelombang $663 \mathrm{~nm}$ (absorbansinya 0,280) dan panjang gelombang $645 \mathrm{~nm}$ (absorbansi 0,113 nm) sehingga kandungan klorofil pada tahapan perkembangan berbeda daun $V$. rubescens $\mathrm{Bl}$. adalah sama, yaitu kandungan klorofil a sebesar 3,25 $\mu \mathrm{g} / \mathrm{g}$ berat basah dan klorofil b sebesar 1,25 $\mu \mathrm{g} / \mathrm{g}$ berat basa. Rata-rata kandungan klorofil total adalah $4,52 \mu \mathrm{g} / \mathrm{g}$ berat basa.
\end{abstract}

Kata kunci: Daun Jilat (Villebrune rubescens B1.), klorofil, perkembangan

\begin{abstract}
Research on Jilat leaf (Villebrune rubescens Bl.) was done to analyze their chlorophyll pigment content of Jilat leaves (V. rubescens) at different developmental levels. The chlorophyll pigment content was analyzed by the use of thin layer chromatography (TLC) method based on spot color and retardation factor. The chlorophylls contents were calculated by Porra et.al. Result showed that Jilat leaf (V. rubescens Bl.) had similar pigment composition consist of carotene, pheophytin a, chlorophyll a, chlorophyll b and xanthophyll. There are color differences in young and adult leaves, but from the measurement results of chlorophyll content show the same absorbance, ie at $663 \mathrm{~nm}$ wavelength (absorbance 0.280) and wavelength $645 \mathrm{~nm}$ (absorbance $0.113 \mathrm{~nm}$ ) so that the chlorophyll content at different stages of development leaves V. rubescens Bl. is the same, namely chlorophyll a content of $3.25 \mu \mathrm{g} / \mathrm{g}$ wet weight and chlorophyll b of $1.25 \mu \mathrm{g} / \mathrm{g}$ base weight. The average total chlorophyll content is $4.52 \mu \mathrm{g} / \mathrm{g}$ base weight.
\end{abstract}

Keywords: Jilat Leave (Villebrune rubescens Bl.), chlorophyll, development.

\section{PENDAHULUAN}

Villebrune rubescens Bl. temasuk dalam suku family Urticaceae yang tumbuh sebagai tanaman hutan basah pegunungan (Suryana et al., 2018; Zuhri et al., 2016; Nawawi et al., 2014), merupakan jenis pohon kecil atau perdu dengan tinggi antara 3-8 meter, tumbuh liar di hutan, (Zulkifli, 2015). Tanaman V. rubescens oleh masyarakat Kepulauan Yapen Provinsi Papua-Indonesia, menyebut tumbuhan ini dengan nama Daun Jilat Darah, namun secara umum dibeberapa wilayah Indonesia lainnya disebut Nangsi, Pinangsi, Pinang-pinang (Mukhti et al., 2012; Nawawi et al., 2014; Suryana et al., 2018). Tanaman ini dilaporkan 
sebagai tanaman asli dari Papua telah digunakan untuk pengobatan penghilang rasa sakit atau memar di masyarakat setempat secara luas. Daun-daun ini dipetik, lalu dihangatkan di atas api lalu ditempelkan ke bagian tubuh yang sakit dan dijilat itu akan memberi efek pendarahan dari tubuh (Gunawan et al., 2018). Di beberapa daerah lain, antara lain Jawa Barat dan Jawa Tengah pemanfaatan daun $V$. rubescens dengan cara merebus dan meminum air rebusan, dipercaya dapat melancarkan buang air kecil dan dapat digunakan untuk mencuci mata yang bengkak (Kusmana \& Hidayat, 2015). Pemanfaatan seperti ini berkaitan erat dengan kandungan kimia, terutama pigmen maupun pada daun tersebut (Sumenda, dkk., 2011).

Kandungan kimia yang terdapat dalam suatu tumbuhan tidak terlepas dari tahap pertumbuhan dan perkembangan tumbuhan tersebut (Sumenda, dkk., 2011). Pertumbuhan dan perkembangan biasanya dipengaruhi oleh faktor eksternal dan internal. Faktor-faktor eksternal utama adalah tanah, kelembaban, cahaya dan air. Faktor-faktor internal dapat mencakup gen, hormon, struktur anatomi dan morfologi organ tumbuhan serta kandungan pigmen (Harahap, 2012).

Pigmen atau zat warna adalah zat yang mengubah warna cahaya tampak sebagai akibat proses absorbsi selektif terhadap panjang gelombang pada kisaran tertentu. Pimen pada tumbuhan terdiri dari dua kelompok besar, yaitu kelompok pigmen klorofil dan karotenoid. Pigmen pada daun berasal berasal dari proplastida yaitu plastida yang belum dewasa, kecil dan hampir tidak berwarna dan sedikit atau tanpa membran dalam (Salisbury \& Ross, 2010). Perbedaan warna daun menunjukkan adanya perbedaan kandungan pigmen daun termasuk pigmen klorofil (Sumenda, dkk., 2011).

Sejauh ini kajian mengenai $V$. rubescens hanya terbatas pada analisis vegetasi dan taksonomi, sedangkan untuk analisis kimia, terutama pigmen belum dilakukan, sehingga penelitian ini dilakukan untuk memberikan informasi ilmiah mengenai kandungan klorofil pada tingkat perkembangan berbeda daun $V$. rubescens. Tujuan penelitian ini adalah untuk mengetahui kandungan klorofil daun $V$. rubescens pada tingkat perkembangan yang berbeda.

\section{METODOLOGI}

Penelitian dilakukan pada bulan April 2018 sampai bulan Mei 2018. Lokasi pengambilan sampel daun $V$. rubenscens di Kampung Turu Distrik Yapen Selatan, Kabupaten Kepulauan Yapen. Teknik pengambilan sampel dilakukan secara purposif sampling dengan mangambil daun pada tingkatan perkembangan yang berbeda. Sedangkan 
untuk analisis kandungan klorofil di Laboratorium Biologi Universitas Cenderawasih Jayapura.

Alat yang digunkan dalam penelitian ini; kantong plastik, kertas label, alat tulis, timbangan analitik, lumpang dan alu porselin, tabung reaksi, rak tabung reaksi, labu ukur, gelas ukur, kertas saringan, termos es, gunting, aluminium foil, kamera digital, plat KLT, dan spectrometer. Sedangkan bahan yang digunakan adalah daun V. rubescens. Aseton 95\%, akuades, es batu, tissue, $\mathrm{Na} 2 \mathrm{SO} 4$ anhidrat, dan $\mathrm{N}$ heksan.

Metode ekstraksi pigmen, dimana sampel dipotong kecil-kecil dan ditumbuk dengan mortar sampai halus, kemudian diambil 3 gr dan diekstraksi menggunakan 95\% aseton. Ekstrak kemudian disaring dengan corong gelas yang ujungnya diberi kapas dan diisi dengan $\mathrm{Na}_{2} \mathrm{SO}_{4}$ anhidrat, residu yang diperoleh diekstraksi kembali dengan pelarut yang sama sampai seluruh pigmen terangkat (El-Mouhty, et.al., 2014; Kong, 2013; Hu et.al., 2013; Putri et.al., 2012).

Analisis pigmen klorofil dengan metode Kromatografi Lapis Tipis (KLT) kuantitatif dilakukan menggunakan pelat KLT silika gel 60 F254 (Merck) ukuran $1 \times 5 \mathrm{~cm}$ sebagai fase diam (Rosang \& Wagey, 2016). Ekstrak pigmen kering dari 3 gr sampel dilarutkan dalam 0,5 ml n-heksana 100\% kemudian diambil $20 \mu 1$ untuk ditotolkan pada pelat KLT menggunakan microsyringe. Warna, kepekatan dan nilai RF setiap totol setelah pelarut mencapai batas akhir dicatat. Analisa kandungan pigmen dengan menggunnakan Spektrofotometer $U V$-VIS pada panjang gelombang pada $\lambda 649$ dan $665 \mathrm{~nm}$. Kadar klorofil total dihitung merujuk Arnon, (1949) dalam Narasimhan, (2015) dengan rumus: Klo. a = 12,7 D-663 - 2,69 D-645 (mg/ 1); Klo. $b=22,9$ D-645 - 4,68 D-663 (mg/ l); dan Klo. Total = 20,2 D-645 + 8,02 D-663 (ml/l).

\section{HASIL DAN PEMBAHASAN \\ Penentuan Konsentrasi Pigmen}

Penentuan konsentrasi pigmen dapat diketahui dengan mengukur absorbansi sampel ekstrak aseton menggunakan spektrofotometer $U V$-Vis. Pengukuran absorbansi dilakukan pada panjang gelombang $645 \mathrm{~nm}$ dan $663 \mathrm{~nm}$ di mana pada panjang gelombang 600an $\mathrm{nm}$ ini merupakan daerah warna merah.

Penggunaan panjang gelombang di daerah warna merah dikarenakan ekstrak pigmen yang diamati berwarna hijau. Warna ini merupakan warna yang diamati, namun warna yang diserap oleh spektrofotometri $U V$-Vis merupakan warna komplementernya. Warna hijau 
memiliki warna komplementer merah. Sehingga, dengan mengetahui absorbansi ekstrak pigmen pada panjang gelombang $663 \mathrm{~nm}$ maka dapat diketahui kandungan klorofil dalam ekstrak tersebut.

Pada pengukuran ini digunakan larutan blanko berupa aseton. larutan blanko ini bertujuan untuk mengetahui besarnya absorbansi terhadap larutan jika tanpa analit. Larutan blanko biasanya digunakan untuk tujuan kalibrasi sebagai larutan pembanding dalam analisis. Pengukurang pigmen dengan menggungunakan spektrofotometri $U V$-Vis pada panjang gelombang $663 \mathrm{~nm}$ dan $645 \mathrm{~nm}$ terhadap daun $V$. rubescens dengan tahapan perkembangan daun dewasa dan daun muda menunjukan nilai absorbansi yang sama, yaitu pada pajang gelombang $663 \mathrm{~nm}$ mendapat absorbansi (D) sebesar 0,280 dan pada panjang gelombang 645 $\mathrm{nm}$, mendapat absorbansi (D) sebesar 0,113. Dari hasil pengukuran, menunjukan kandungan klorofil a pada daun $V$. rubescens sebesar 3,25 $\mu \mathrm{g} / \mathrm{g}$, klorofil b sebesar 1,25 $\mu \mathrm{g} / \mathrm{g}$, sehingga di peroleh total klorfil pada daun $V$. rubescens adalah sebesar $4,52 \mu \mathrm{g} / \mathrm{g}$.

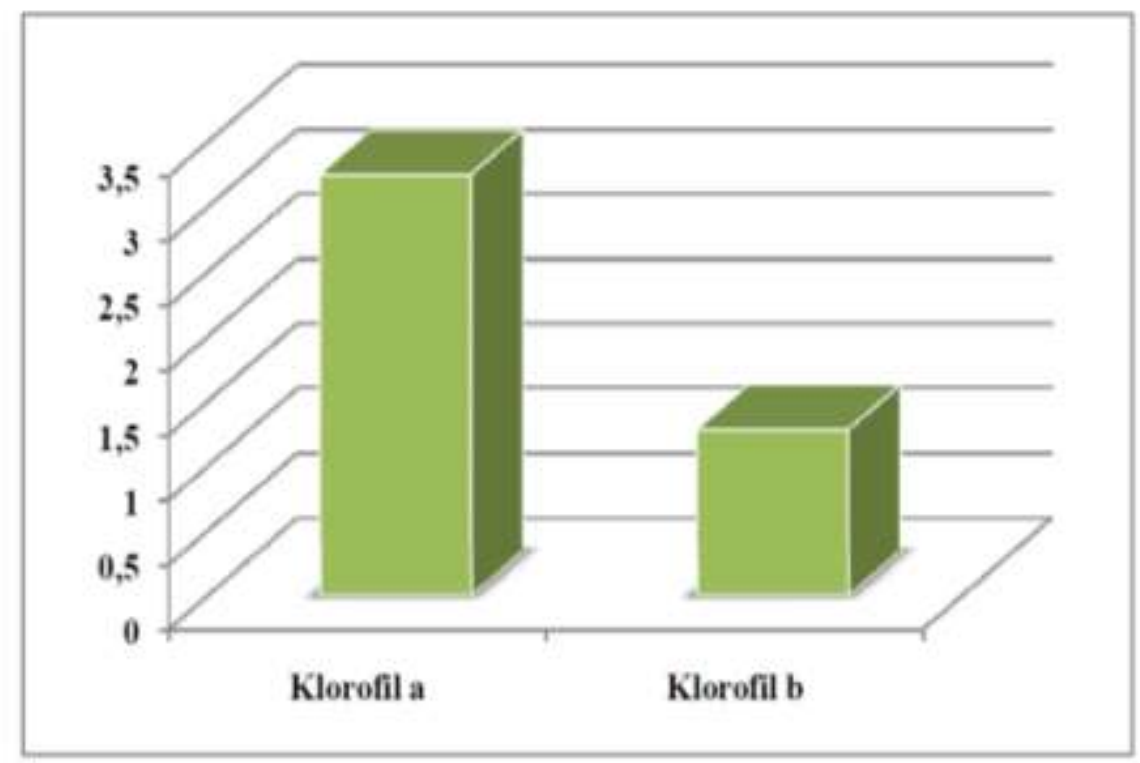

Gambar 1. Konsentrasi Pigmen Klorofil pada Daun V. rubescens dengan tahapan perkembangan daun dewasa dan daun muda

\section{Penentuan Pigmen dengan KLT}

Analisa komposisi pigmen penyusun daun $V$. rubescens dengan tahapan perkembangan daun dewasa dan daun muda dilakukan menggunakan metode Kromatografi Lapis Tipis (KLT), berdasarkan warna totol dan nilai retardasi faktor (Rf). Pola pemisahan pigmen pada daun $V$. rubescens disajikan pada Gambar 2. 

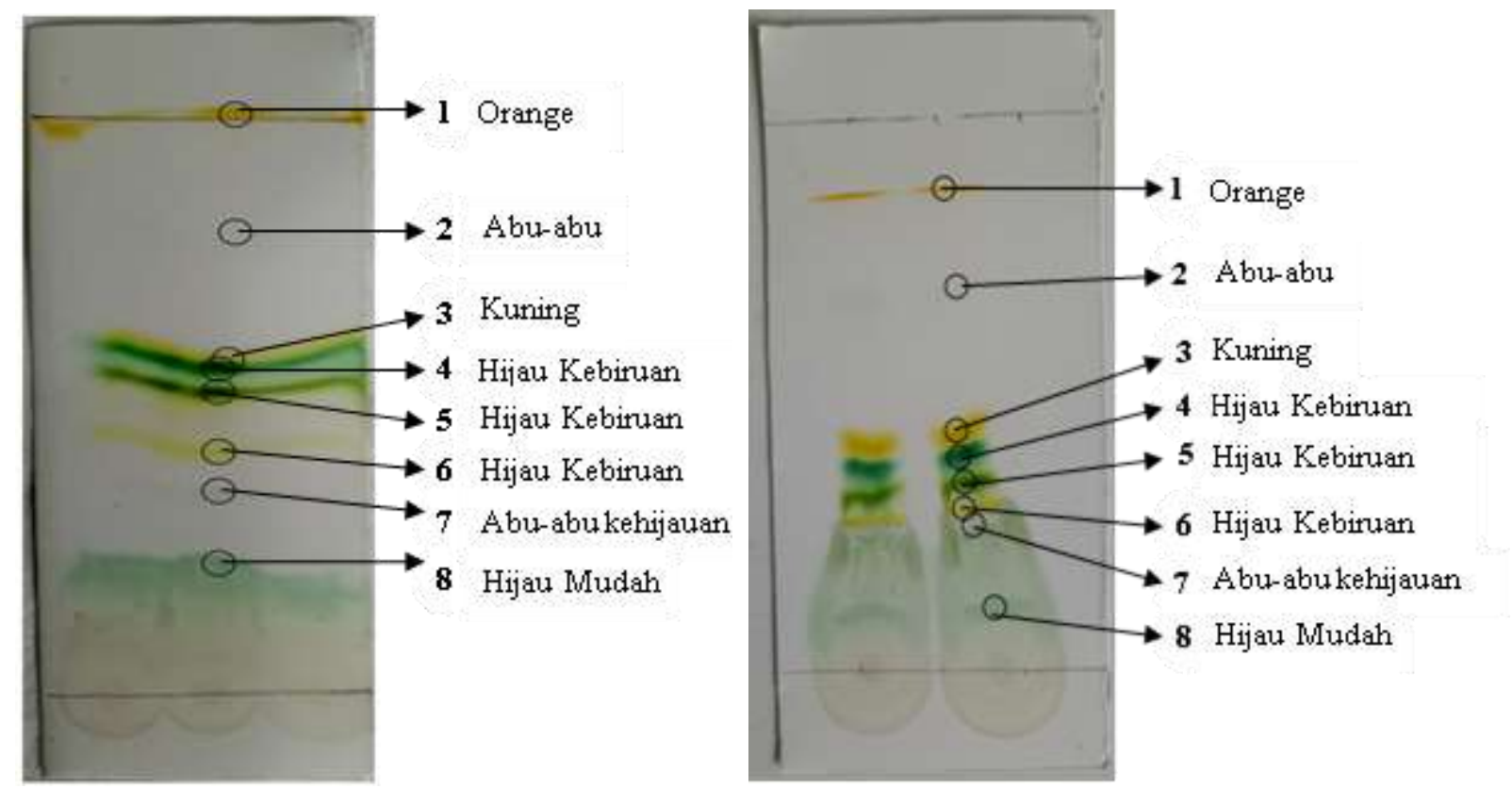

Gambar 2. Pola pemisahan pigmen daun $V$. rubescens pada tahapan perkembangan daun Dewasa (A) dan daun Muda (B).

Jumlah pigmen yang terdapat dalam daun $V$. rubescens dapat diketahui berdasarkan jumlah totol yang muncul pada pelat KLT. Gambar 2 menunjukkan jumlah dan komposisi pigmen daun $V$. rubescens pada tahapan perkembangan daun dewasa dan daun muda yaitu 8 totol dengan komposisi pigmen berturut-turut sebagai berikut: orange (totol 1), abu-abu (totol 2), kuning (totol 3), hijau kebiruan (totol 4), hijau kekuningan (totol 5), kuning (totol 6), abuabu kehijauan (totol 7), dan hijau muda (totol 8). Perbedaan kepekatan warna totol pigmen yang nampak pada pemisahan pigmen tersebut berkaitan dengan konsentrasi pigmen yang terkandung didalamnya.

Warna yang ditunjukkan dalam pemisahan pigmen pada KLT dapat digunakan sebagai dasar untuk identifikasi pigmen (David, 2010). Totol 1 (orange) merupakan karoten, totol 4 (hijau biru) klorofil $\boldsymbol{a}$, totol 5, 8 (hijau kuning) klorofil $\boldsymbol{b}$ dan totol 3 (kuning) serta totol 6 (kuning) merupakan ksantofil. Data ini sesuai dengan deskripsi (Gross, 1991), yang menyatakan bahwa klorofil $\boldsymbol{a}$ berwarna hijau biru, klorofil $\boldsymbol{b}$ hijau kuning dan karotenoid berwarna kuning, orange, merah. Menurut Gross (1991), karotenoid dibedakan menjadi dua golongan utama yaitu: karoteniod polar (ksantofil) dan karotenoid non polar (karoten). Totol 2 dan 7 (abu-abu) diduga merupakan feofitin $a$. Hal ini didukung Wang \& Hwang, (1995), yang mengidentifikasikan warna abu-abu sebagai feofitin $a$. 
Tabel 1. Nilai Rf pigmen Daun V.rubescens pada daun Muda dan Daun Dewasa

\begin{tabular}{lccc}
\hline \multirow{2}{*}{ Totol ke- } & \multicolumn{3}{c}{ Nilai Rf } \\
\cline { 2 - 4 } & Daun Muda & Daun Dewasa \\
\hline 1 & 0,87 & 1 \\
2 & 0,68 & 0,78 \\
3 & 0,42 & 0,6 \\
4 & 0,38 & 0,57 \\
5 & 0,33 & 0,53 \\
6 & 0,3 & 0,43 \\
7 & 0,25 & 0,35 \\
8 & 0,12 & 0,23 \\
\hline Analisa & retardasi faktor (Rf) perlu dilakukan untuk & memperkuat identifikasi
\end{tabular}
komposisi pigmen berdasarkan warna (Daood et.al., 1987). Tabel 1 menunjukkan kisaran nilai Rf pigmen daun $V$. rubescens dengan tahapan perkembangan daun dewasa dan daun muda. Keragaman nilai Rf pigmen berkaitan erat dengan kandungan pigmen penyusun tumbuhan tesebut. Hal ini didukung oleh (Alegantina \& Isnawati, 2010) yang menyatakan bahwa nilai Rf bervariasi tergantung pada pelarut, penjerap, suhu, kemurnian, dan konsentrasi pigmen.

Hasil penelitian menunjukkan bahwa nilai Rf karoten (orange) 0,87, sedangkan ksantofil (kuning) berkisar antara 0,3-0,78 dan (orange) 0,87-1, memiliki kecenderungan yang sama dengan nilai $\mathrm{Rf}$ karoten 0,91-0,94 dan ksantofil 0,20-0,26 menggunakan fase diam dan fase gerak yang sama (Heriyanto \& Limantara, 2009). Britton \& Pfander (1995), juga memberikan hasil yang sama, dimana nilai Rf karoten 0,88 dan ksantofil 0,10-0,30 dalam pelarut aseton heksana dengan perbandingan $5: 95(\mathrm{v} / \mathrm{v})$. Meskipun fase gerak yang digunakan memiliki komposisi yang berbeda, namun dominansi sifat non polar pada toluen dan heksan sama-sama kuat. Kisaran nilai Rf feofitin $a$ (abu-abu) 0,25-0,78, klorofil $a$ (hijau biru) 0,38-0,57; klorofil $b$ (hijau kuning) 0,12-0,53, memiliki kecenderungan yang sama dengan yang dilaporkan Madalena (2004) dalam Heriyanto \& Limantara, (2009), dimana nilai Rf feofitin $a$ 0,76-0,89; klorofil $a$ 0,40-0,63; klorofil $b$ 0,30-0,57.

\section{Kandungan Pigmen}

Pada penelitian ini diperoleh hasil, daun $V$. rubescens dewasa memiliki kandungan klorofil lebih tinggi dibandingkan daun $V$. rubescens yang muda. Hal ini tidak sesuai dengan pendapat (Salisbury \& Ross, 2010) tentang umur daun sangat mempengaruhi proses fotosintesis, dimana proses penuaan akan berdampak pada kelambanan proses fotosintesis. 
Sehingga daun yang dewasa memiliki kadar klorofil yang rendah. Namun dalam beberapa kondisi, seringkali nutrisi lebih sering didistribusikan ke daun yang lebih dewasa dari pada daun yang lebih muda, sehingga klorofil lebih tinggi daun setengah dewasa lebih tinggi dibandingkan pada daun yang muda.

Bisa juga klorofil total lebih banyak pada daun dewasa karena kadar klorofil berdasarkan tiap-tiap umur daun yakni daun muda dan daun dewasa disebabkan oleh beberapa faktor diantaranya faktor internal dan faktor eksternal (Sumenda, dkk., 2011). Kandungan klorofil pada suatu daun akan meningkat sejalan dengan bertambahnya umur daun. Peningkatan ini terjadi sejalan dengan pertumbuhan dari daun muda menjadi daun dewasa, tumbuhan masih melakukan biosintesis klorofil. Berdasarkan struktur dan kandungan dari daun dewasa lebih banyak membutuhkan nutrisi untuk keperluan hidup yakni sebagai sumber energi, maka dapat dikatakan bahwa daun dewasa masih melakukan biosintesis klorofil. Sedangkan pada daun yang masih muda, kandungan klorofilnya masih sedikit, karena daun ini belum banyak melakukan biosintesis klorofil. Dalam hal ini selain faktor internal, perbedaan kandungan klorofil juga dapat dipengaruhi oleh faktor eksternal, diantaranya intensitas cahaya, naungan, morfologi, dan luas permukaan daun. Besar intensitas cahaya yang di terima atau absorbsi daun bargantung dari jumlah klorofil yang di miliki daun tersebut.

Selain itu tempat tumbuh $V$. rubescens berpengaruh pada besarnya kandungan klorofil, dimana tumbuhan $V$. rubescens yang tumbuh pada daerah yang ternaung, secara pengamatan warna daunnya tidak sehijau dan sesegar daun $V$. rubescens yang berada bebas (tidak ternaung). Secara kasat mata, perbedaan kandungan klorofil daun $V$. rubescens daun dewasa dan daun muda dapat dilihat dari perubahan penampakan warna tersebut, dimana pada daun muda menunjukan warna hijau muda kemerahan, sedangkan pada daun dewasa menunjukan warna hijau tua dengan pertulangan daun berwarna merah. Tanaman yang tumbuh di kondisi ternaung akan memiliki kandungan klorofil lebih tinggi daripada tanaman yang tumbuh di kondisi tidak atau kurang ternaung (Sumenda, dkk., 2011).

Kandungan karotenoid pada daun $V$. rubescens muda lebih tinggi daripada daun $V$. rubescens dewasa, hasil ini berkaitan dengan adanya sintesis karotenoid pada daun muda $V$. rubescens. Keberadaan karotenoid di dalam tumbuhan tingkat tinggi memainkan peranan penting sebagai pelindung klorofil terhadap cahaya atau sebagai fotoprotektor (MathewsRoth, 1982). 


\section{KESIMPULAN}

Tumbuhan $V$. rubescens dengan tahapan perkembangan daun berbeda (daun dewasa dan daun muda) mempunyai komposisi pigmen utama yang sama yaitu karoten, feofitin a, klorofil a, klorofil b dan ksantofil. Terdapat perbedaan warna pada daun muda dan dewasa, namun dari hasil pengukuran kandungan klorofil menunujukan absorbansi yang sama, yaitu pada panjang gelombang $663 \mathrm{~nm}$ (absorbansinya 0,280) dan panjang gelombang $645 \mathrm{~nm}$ (absorbansi 0,113 nm) sehingga kandungan klorofil pada tahapan perkembangan berbeda daun $V$. rubescens adalah sama, yaitu kandungan klorofil a sebesar 3,25 $\mu \mathrm{g} / \mathrm{g}$ berat basah dan klorofil b sebesar $1,25 \mu \mathrm{g} / \mathrm{g}$ berat basa. Rata-rata kandungan klorofil total adalah $4,52 \mu \mathrm{g} / \mathrm{g}$ berat basa.

\section{REFERENSI}

Alegantina, S., \& Isnawati, A., 2010. Identifikasi dan Penetapan Kadar Senyawa Kumarin Dalam Ekstrak Metanol Artemisia annua L. Secara Kromatografi Lapis TipisDensitometri. Buletin Penelitian Kesehatan. Vol. 38 No 1, 17-28.

Britton G, S. L., J., \& Pfander, H., 1995. Carotenoids (IA): Isolation and Analysis. Switzerland: Birkhauser Verleg.

David, 2010. Pengantar Kromatografi. ITB Bandung Press. Bandung.

Daood, H. G., Biacs, P., \& Hoschke, A., 1987. Separation and identificatio of tomato fruit pigments by TLC and HPLC. Acta Aliment. Vol. 16, 339-350.

El-Mouhty, R.A, N., \& El-Naggar, A. Y., 2014. Extraction of Chlorophyll and Carotene from Irradiated Parsley. International Journal of Innovative Research in Science. Vol.3 No.1, 8522-8527.

Gunawan, E., Dirgantara, S., Simaremare, E. S., \& Pratiwi, R. D., 2018. Antibacterial Activity of Daun Jilat Extract (Villebrunea rubescens) Papua to Staphylococcus aureus and Escherichia coli Bacterial. Advanced Science Letters, Vol. 24 (1): 84-87. DOI: https://doi.org/10.1166/asl.2018.11927

Gross, 1991. Pigments In Vegetables: Chlorophyll an Carotenoids. Van Nostrand Reinhold. New York.

Harahap, F., 2012. Fisiologi Tumbuhan. Perdana Mulya Sarana. Medan.

Heriyanto, \& Limantara, L., 2009. Komposisi dan Kandungan Pigmen Utama Tumbuhan PutriMalu (Cucuta australis R.Br dan Cassytha filiformis L. Makara Sains, Vol. 10 (2): 69-75.

Hu, X., Tanaka, A., \& Tanaka, R., 2013. Simple Extraction Methods that Prevent the Artifactual Conversion of Chlorophyll to Chlorophyllide during Pigment Isolation from Leaf Samples. Plant Methods, Vol 9, 19-31.

Kusmana, C. \& Hidayat, A., 2015. Keanekaragaman Hayati Flora Indonesia. Jurnal Pengelolaan Sumberdaya Alama dan Lingkungan, Vol. 5(2): 187-198. 
Kong, E., 2013. Optimization of Ultrasound-assisted Extraction Parameters of Chlorophyll from Chlorella vulgaris Residue after Lipid Separation using Response Surface Methodology. Journal of Foot Science technology, Vol. 51, 51-55.

Mukhti, R.P., Syamsuardi, dan Chairul, 2012. Jenis-Jenis Balanophoraceae Di Sumatera Barat. Jurnal Biologi Universitas Andalas, Vol. 1 (1): 15-22

Mathews-Roth, M., 1982. Carotenoid Chemistry and Biochemistry. Pergamon Press. Oxford.

Narasimhan, B., 2015. Extraction and estimation of chlorophyll from medicinal plants. International Journal of Science and Research (IJSR). Vol. 4, 209-2012.

Nawawi, G. R.N., Indriyanto, dan Duryat, 2014. Identifikasi Jenis Epifit Dan Tumbuhan Yang Menjadi Penopangnya Di Blok Perlindungan Dalam Kawasan Taman Hutan Raya Wan Abdul Rachman. Jurnal Sylva Lestari. Vol. 2 (3): 39-48

Putri, W. D. R., \& Zubaidah, E., Sholahudin N., 2012. Ekstraksi Pewarna Alami Daun Suji, Kajian Pengaruh Blanching dan Bahan Pengekstrak. Jurnal Teknologi Pertanian, Vol 4(1): 13-24.

Rosang I, C., \& Wagey, B. T., 2016. Penentuan Kandungan Pigmen Klorofil pada Lamun Jenis Halophila ovalis di Perairan Malalayang. Pesisir dan Laut Tropis, Vol. 1: 15-19.

Salisbury, F., \& Ross, W., 2010. Fisiologi Tumbuhan Jilid 2 Edisi Revisi. ITB Bandung. Bandung.

Sumenda, L., Rampe, L H., \& Mantiri, F. R., 2011. Analisa Kandungan Klorofil Daun Mangga (Mangifera indica L.) pada Tingkat Perkembangan Daun yang Berbeda. Bioslogos, 20-24.

Suryana, Iskandar, J., Parikesit, Partasasmita, R., dan Irawan, R., 2018. Struktur Vegetasi Kawasan Hutan Pada Zona Ketinggian Berbeda di Kawasan Gunung Galunggung Kabupaten Tasikmalaya Jawa Barat. Jurnal ilmu lingkungan. Vol.16 (2):130-135

Wang, B. J., Yu, Z.R., \& Hwang, L.S., 1995. Quantitative Analysis of Chlorophylls and Their Derivatives. Journal of the Chinese Agricultural Chemical Society, 550-560.

Zulkifli M., 2015. Dinamika Populasi dari Villebrunea rubescens (B1.) di Plot Permanen Bukit Gajabuih Ulu Gadut. (Skripsi). Fakultas Matematika dan Ilmu Pengetahuan Alam. Universitas Andalas, Padang. http://scholar.unand.ac.id/1428/

Zuhri, M., Wiriadinata, H., Astuti, R. S., Hadiwaluyo, S., dan Syamsudin. 2016. Botanical Exploration and Crater Vegetation Survey of Mt. Galunggung, West Java. The Journal Of Tropical Life Science. Vol. 6 (2): 69 - 78. doi: 10.11594/jtls.06.02.02 